\title{
Erratum to: Rapid progression of intracranial melanoma metastases controlled with combined BRAF/MEK inhibition after discontinuation of therapy: a clinical challenge
}

Daniel N. Cagney ${ }^{1} \cdot$ Brian M. Alexander $^{1} \cdot$ F. Stephen Hodi ${ }^{2}$. Elizabeth I. Buchbinder ${ }^{2} \cdot$ Patrick A. Ott $^{2} \cdot$ Ayal A. Aizer ${ }^{1}$

Published online: 19 May 2017

(C) Springer Science+Business Media New York 2017

Erratum to: J Neurooncol (2016) 129:389-393

DOI 10.1007/s11060-016-2196-8

The first author's middle initial was incorrectly captured as part of the surname in the metadata of the original publication.

The online version of the original article can be found under doi:10.1007/s11060-016-2196-8.

Daniel N. Cagney

dcagney@1roc.harvard.edu

1 Department of Radiation Oncology, Brigham and Women's Hospital, Harvard Medical School, 75 Francis Street, Boston, MA 02115, USA

2 Department of Medical Oncology, Dana-Farber Cancer Institute, Harvard Medical School, Boston, MA, USA 